\title{
Enhancing the Language Learning Process of Students in the Costa Rican Educational System by Considering the Use of Authentic Materials in the EFL Classroom
}

\author{
Margoth Arley-Fonseca* \\ https://orcid.org/0000-0003-0881-4714 \\ Tobías Brizuela-Gutiérrez** \\ https://orcid.org/0000-0001-7291-0634
}

Recibido: 30 de octubre de 2019 - Aceptado: 19 de mayo de 2020

\begin{abstract}
Each student has different personality traits and processes information in multiple ways. Learning takes place more effectively when conditions are optimal and enriching. Teachers should provide students with meaningful and authentic materials in order to guarantee and help students attain their own learning.

The following article intends to offer practical ideas on how to incorporate authentic materials in the teaching process as vehicles to help students get the most out of them in order to enhance their learning development. The expressed ideas will focus on receptive skills; that is to say, aural and reading skills. A connection to the implementation of the new syllabus of the Ministry of Public Education (MEP), the «Action Oriented Approach», is also addressed in the following paragraphs.
\end{abstract}

Key words: Learning, authentic materials, communication, Action Oriented Approach.

\footnotetext{
${ }^{*}$ Máster en Administración Educativa, Universidad de Costa Rica (UCR), Costa Rica. Licenciada en Lengua Inglesa y bachiller en la Enseñanza del Inglés, UCR. Profesora y asistente académica de la carrera Enseñanza del Inglés para I y II Ciclos, de la Universidad Estatal a Distancia (UNED), de Costa Rica. Correo: marley@uned.ac.cr

** Master en Educación con Énfasis en la Enseñanza del Inglés, Universidad Latina de Costa Rica. Licenciado en Educación con Énfasis en Currículo y Evaluación, Universidad de las Ciencias y el Arte, de Costa Rica. Bachiller en la Enseñanza del Inglés para I y II ciclos, Universidad Estatal a Distancia (UNED). Encargado de la Cátedra de Enseñanza del Inglés de la Escuela de Ciencias Sociales y Humanidades, de la UNED. Profesor titular del área de Enseñanza del Inglés y docente de grado de asignaturas relacionadas con la carrera de Enseñanza del Inglés para I y II ciclos, de la UNED. Correo: tbrizuela@uned.ac.cr
} 
Mejoramiento del proceso de aprendizaje del idioma extranjero de los estudiantes del sistema educativo costarricense por medio del uso de materiales auténticos en la clase de idioma

\section{Resumen}

El profesor de inglés como lengua extranjera debe tomar en consideración las diversas personalidades y múltiples formas para procesar la información de los estudiantes. Indudablemente, el aprendizaje del inglés ocurre de manera efectiva cuando las condiciones son óptimas y enriquecedoras. Para promover el aprendizaje significativo, el profesor de inglés debe utilizar diversos tipos de materiales de enseñanza, métodos y técnicas.

Este artículo busca ofrecer ideas prácticas para incorporar materiales auténticos en el proceso de enseñanza como vehículo para ayudar a los estudiantes a obtener lo máximo en el desarrollo de sus habilidades lingüísticas. Las ideas expresadas se enfocarán en las habilidades receptivas, siendo así, las habilidades de escucha y lectura. Definiciones, clasificaciones, tipos de materiales, ventajas, desventajas y ejemplos serán examinados, así como la justificación y conexión con la implementación del nuevo currículo del Ministerio de Educación Pública (MEP), denominado «Action Oriented Approach».

Palabras clave: Aprendizaje, materiales auténticos, comunicación, Metodología orientada en la acción (AOA).

Amélioration du processus d'apprentissage de la langue étrangère chez les apprenants du système éducatif costaricien au moyen de l'utilisation de matériaux authentiques dans la classe de langue

\section{Résumé}

L'enseignant d'anglais langue étrangère doit prendre en considération les diverses personnalités et les multiples façons pour traiter l'information des apprenants. Indiscutablement, l'apprentissage de l'anglais se produit de manière effective quand les conditions sont optimales et enrichissantes. Afin de promouvoir l'apprentissage significatif, l'enseignant d'anglais doit utiliser différents matériaux d'enseignement, méthodes et techniques.

Cet article vise à offrir des idées pratiques pour intégrer des matériaux authentiques dans le procès d'enseignement en tant que moyen pour aider les apprenants à atteindre le développement maximal de leurs habilités linguistiques. Ces idées se centrent sur les activités de réception, proprement, la l'écoute et la lecture. Les définitions, classifications, les types de matériaux, les avantages, les inconvénients et les exemples seront examinés ainsi que la justification et le rapport avec la mise en place du nouveau programme du Ministère de l'Éducation Publique appelé «Perspective actionnelle».

Mots-clés: Apprentissage, matériaux authentiques, communication, perspective actionnelle (P.A.). 


\section{An Introduction to Meaningful Learning}

Richards and Renandya ${ }^{1}$ state «Learning is an essential human activity around the world». The learning environment should consider that each student has different personality traits and processes information in multiple ways. Learning takes place more effectively when conditions are optimal and enriching. A variety of different kinds of teaching materials, methods and techniques will undoubtedly provide students with many opportunities to enhance their learning journey.

One of the most important goals in teaching is student achievement. By creating a non- threatening and motivating environment, planning lessons considering all possible kinds of activities, and providing students with meaningful and authentic materials, teachers can guarantee and help students attain this important goal. In regards to selecting materials, teachers should carefully incorporate the best resources to help students boost and maximize their language acquisition process. By using the most appropriate materials, teachers ensure a learning process that will definitely equip students to face the real world.

The following article intends to offer practical ideas on how to incorporate authentic materials in the teaching process as vehicles to help students get the most out of them in order to enhance their learning development. The ideas expressed will focus on receptive skills, that is to say, aural and reading skills. Definitions, classifications, types of materials, advantages and examples will be provided as well as a justification and connection to the implementation of the new syllabus of the Ministry of Public Education (MEP), the Action Oriented Approach. Also, the opinions and contributions of 35 English teachers collected from a survey will be analyzed to illustrate some sections of this article.

\section{Justifying the Use of Authentic Materials as the Means for Language Development}

Authenticity of the language can be defined as a genuine and real act of communication that evidences normal characteristics of the use of the language such as interruptions, false starts, differences in accents, and paraphrasing, among others. In order to satisfy the communication needs of learners, English as a Foreign Language (EFL) teachers are required to implement communicative tasks and comprehension exercises that reflect the authentic use of the language in everyday situations. This teaching practice provides learners opportunities to extract information meaningfully and get prepared to face real life communication.

In EFL classrooms, teachers can incorporate authentic materials presented in an aural or written form such as newspaper articles, recipes, lyrics, manuals, cellphone messages, TV news, radio programs, and weather forecasts. These materials are typically used in everyday contexts and situations in English speaking countries. Additionally, in present days, thanks to the access to mass media and Internet

1 Jack Richards and Willy Renandya, Methodology in Language Teaching (Cambridge University Press, 2002), 19.

ESPIGA'] (1) (2) (2) Año 20, N.o 40: 121-139, julio - diciembre 2020 
connectivity, EFL teachers can easily obtain these materials from a variety of sources.

When planning classes based on the use of authentic materials, EFL teachers need to select activities considering one caveat: examining authentic language use requires more in-depth analysis and the application of learning strategies to avoid confusion and demotivation. In this learning context, during the presentation stage, learners' receptive skill can be confirmed based on their performance when working on the selected activities.

When using authentic materials, Holden, Brown, Hedge and Ur propose the possibility of preparing learners to apply strategies to firstly check their comprehension $^{2}$. Even though some characteristics of authentic materials such as the lack of knowledge about the topic and context may confuse the learner, these strategies should facilitate the process of comprehension while equipping them to become successful in the real world. As a matter of fact, MEP in Costa Rica is promoting the use of authentic materials as a key component of the teaching-learning process when implementing the new syllabus, well-known as the Action Oriented Approach.

MEP decided to change its syllabus in 2017 with the purpose of contributing to the formation of the new citizens the country needs. Having that goal in mind, MEP implemented the Action Oriented Approach with the intention of transforming English Classrooms across Costa Rica.

The main reasons of adopting a new syllabus state that ${ }^{3}$ :

1. Learners need an updated curriculum that reflects the knowledge, skills, and abilities needed to succeed in the information age as $21^{\text {st }}$ century learners.

2. Pre-school, elementary and secondary school's curriculum required an update in order to have more pertinent target content.

3. Learners who receive English lessons in elementary and high schools are not reaching the expected English proficiency levels after eleven or twelve years of instruction.

4. Citizens need to possess a number of competences to communicate effectively in the global context and to face the challenges of an interconnected world.

Considering the previous reasons, MEP's official document refers to different basic principles of the Action Oriented Approach that will permeate pedagogy and teaching practices. Its principle number 4 is clear when talking about using materials:

Learners use authentic materials as comprehensible input, as much as possible. In that sense, oral or written authentic texts can take advantage of business cards, bus tickets, newspaper articles, book excerpts, wikis, bus schedules, city maps, bulletin boards, voice messages, and announcements.

${ }^{2}$ Pat Wilcox Peterson, Skills and strategies for proficiency listening (2001), 87-100.

${ }^{3}$ Ministry of Public Education (MEP), Transforming the English Classroom through ActionOriented Teaching and Learning, San José, Costa Rica (2016), 11.

ESPIGA- @(1) (1) Año 20, N.o 40: 121-139, julio - diciembre 2020 
Those materials should be appropriate to the learner's needs and competence level and foster an intercultural perspective. ${ }^{4}$

\section{Defining Authentic Materials}

An authentic material can be defined as any type of text that has not been created for instructional purposes. Gower and Walters explain that «anything a native speaker of English would hear or read or use can be described as authentic ${ }^{5}$. Based on the fact that an authentic material is not designed for teaching EFL students, these materials cannot be classified according to particular proficiency levels or specific language contents. However, EFL teachers who are interested in implementing these materials in their classes with the sake of resembling real life situations may feel the need to classify them based on their level of difficulty. EFL teachers may take into consideration factors such as cultural backgrounds, language use, rhetoric, syntax, length, and others in order to adapt the authentic materials to their students' linguistic levels.

Undoubtedly, in Costa Rica, EFL teachers also have to take into consideration that in public schools and high schools, students only receive from 3 to 5 English lessons per week. This minimum exposure to English classes, regularly based on academic textbooks and handouts designed for pedagogical purposes do not fully prepare students with the linguistic tools to be part of real life communication. To actually attain this goal, authentic materials are unquestionably a more attractive possibility for EFL students who come from particular non-English speaking countries such as Costa Rica.

In a survey conducted with 35 teachers of different educational regions in Costa Rica, they were asked if they were familiar with this concept of authentic materials. Their answers are shown in the following chart: ${ }^{6}$

Table 1 Survey questión and answers

\begin{tabular}{|l|c|c|}
\hline \multicolumn{1}{|c|}{ Question } & Yes & No \\
\hline $\begin{array}{l}\text { Are you familiar with the } \\
\text { concept of authentic } \\
\text { materials in the Action } \\
\text { Oriented Approach? }\end{array}$ & 23 teachers & 12 teachers \\
\hline
\end{tabular}

Source: Taken from the survey, July 2019.

From these 23 teachers who claimed they were familiar with authentic materials, they were asked to identify words and phrases linked to the concept of authentic materials, some teachers mentioned the following: ${ }^{7}$

${ }^{4}$ Ibíd, 31.

${ }^{5}$ Roger Gower and Steve Walters, Teaching Practice: A handbook for teachers in training (Thailand: Macmillan, 1995), 82.

${ }^{6}$ Margoth Arley and Tobías Brizuela, Survey, July 2019.

7 Ibíd.

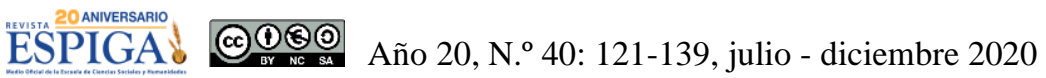


Table 2 Words and phrases linked to the concept of authentic materials

\begin{tabular}{|l|l|}
\hline Teacher 1 & $\begin{array}{l}\text { Real life, accessible materials (you can find it everywhere), } \\
\text { low-cost/affordable }\end{array}$ \\
\hline Teacher 2 & Real- interactive- thought provoking \\
\hline Teacher 3 & Contextualized, updated, inclusive \\
\hline Teacher 4 & Genuine- real- meaningful \\
\hline Teacher 5 & Daily use - for communication purposes \\
\hline Teacher 6 & Realia, design not for teaching, real contexts \\
\hline Teacher 7 & Real language, real situations, non- pedagogical purpose \\
\hline Teacher 8 & Necessary, interesting, dynamic \\
\hline Teacher 9 & Real life situations \\
\hline Teacher 10 & It is any material that students encounter in their daily lives \\
\hline
\end{tabular}

Source: Taken from survey, July 2019.

Based on these answers, one concludes that these interviewed teachers acknowledge authentic materials as texts that contain real life and contextualized language that is examined and used with meaningful communication purposes. It is evident that many of the interviewed teachers are familiar with the topic being discussed in this article and this fact reveals that these types of materials have now become part of their regular planning so their pedagogical mediation is now intended to helping the learner become autonomous and successful in the completion of the different learning tasks.

Geddes and White (as cited in Hedge) state that EFL teachers can use two types of aural and written materials with the sake of promoting meaningful learning:

-Materials that include «language originally written or spoken for a non-pedagogical purpose, which was, in its original context, a genuine act of communication». Some examples of this type of material are flyers, TV advertisements, magazine articles, blogs, and radio talk shows that are found in mass media.

-Materials that incorporate «language produced for a pedagogical purpose, but exhibiting features that have a high probability of occurrence in genuine acts of communication». Some examples of this type of material are menus, newspaper articles, and telephone conversations designed by the EFL teacher, considering students' learning goals and levels, but evidencing a natural use of the language ${ }^{8}$.

Based on this premise, in order to satisfy students' communication needs, EFL teachers may design activities based on the use of materials, designed either with a pedagogical or non-pedagogical objective. The balance on the use of these two types of materials can promote students' meaningful learning, through the exposure and analysis of authentic language use and the improvement of students' receptive skills.

8 Tricia Hedge, Teaching and learning in the language classroom (New York: Oxford University Press, 2000), 246. 
As in any EFL class, after setting up the tone of a lesson through a warm-up activity, EFL teachers have to firstly introduce the content given in any type of written or aural material. To do this, according to Ellis ${ }^{9}$, «it is axiomatic that in order for Second Language Acquisition to take place, there must be (1) some L2 data made available to the learner as input and (2) a set of internal learner mechanisms to account for how the L2 data are processed». To expose learners to comprehensible input, Stephen Krashen claims in his Input Hypothesis theory that «the language that learners are exposed to should be just far enough beyond their current competence that they can understand most of it but still be challenged to make progress ${ }^{10}$. In this sense, when designing activities based on the examination of authentic materials, EFL teachers have to attentively make the necessary adaptations to the material so that the input is comprehensible enough. Harmer cautions that an «authentic material which has been carelessly chosen can be extremely demotivating for students since they will not understand it» ${ }^{11}$.

To avoid confusion, Harmer advises teachers to use their roughly-tuned language and design their own written and oral texts based on true authentic materials, with one caveat, such texts must resemble the concept of authenticity. This author clarifies that «language may be simplified, but it must not be unnatural» ${ }^{12}$. Harmer's recommendation agrees with Krashen's Input Hypothesis theory in the sense that EFL teachers ought to make the necessary adjustments to the authentic materials considering students' language skills and learning goals. When making the correct adaptations, EFL teachers are ensuring that the incorporation of authentic language input is not going to diminish students' motivation to learn the language.

\section{A Closer Look to Authentic Aural Materials}

Considering Ellis' theory on how to introduce language input, EFL teachers should first establish the learning objectives when enhancing particular skills. In the case of the listening skill, Underwoods ${ }^{13}$ claims that aural materials can be classified based on the listeners' objectives as:

-Listening to live conversations in which one takes no part and the purpose is curious eavesdropping.

-Listening to announcements, news items, and weather forecasts with the purpose of extracting information.

-Listening to or watching plays, radio and TV entertainment, and listening to songs with the purpose of enjoyment.

-Following instructions in order to efficiently carry out a task.

-Attending a lecture or following a lesson in order to understand concepts and information.

-Listening to someone give a public address in order to infer views and attitudes.

\footnotetext{
${ }^{9}$ Rod Ellis, Understanding Second..., 127.

${ }^{10}$ Douglas Brown, Teaching by principles (New York: Addison Wesley Longman, 2007), 295.

${ }^{11}$ Jeremy Harmer, The Practice of English Language Teaching (England: Pearson, 2008), 273.

12 Ibíd., 273.

13 Tricia Hedge, Teaching and..., 243.

ESPIGAd (1) (1) (2) Año 20, N. ${ }_{\text {ay }}^{\text {nave }}$ 40: 121-139, julio - diciembre 2020 
When examining this variety of listening objectives, EFL teachers have to carefully select the internal mechanisms that will be needed so that students can easily process data. Harmer explains that there are two types of tasks learners should go through when analyzing aural texts: type 1 tasks refer to those in which students listen to get the gist of the text. On the other hand, in type 2 tasks, students «pick out details or get involved in a refined search of the text». In the latter, students have to «look at the text in considerably more detail, maybe for specific information or for language points». Harmer explains that by moving from type 1 tasks to type 2 tasks, students «get a feel for what they are seeing or hearing before they have to attack the text in detail, which is the more difficult thing to do» ${ }^{14}$.

Unquestionably, listening to an authentic material requires students to attentively try to get as much information as possible. In Davies' words, «unlike reading texts, the speed and clarity of spoken texts are completely outside the listener's control» ${ }^{15}$. Harmer also warns that when students are listening to an authentic material, because of unknown lexis, they may miss the next parts of the speech; therefore, comprehension may gradually degrade. For all these reasons, to avoid confusion and demotivation, EFL teachers have to carefully introduce English language features such as phonetics, morphology and content knowledge. Last of all, EFL teachers have to guide students to predict future outcomes and link what they are listening to with what they know about their world.

\section{A Closer Look to Authentic Written Materials}

It is undeniable that the EFL teacher plays a critical role when providing the necessary environment for students to acquire language skills, especially when trying to set up a more genuine context for promoting language use. Ellis explains that «language acquisition derives from the collaborative efforts of the learner and his interlocutors and involves a dynamic interplay between external and internal factors ${ }^{16}$. In this scenario, the EFL teacher can establish the external factors that may come to place so that language communication is fluent and natural. With the sake of providing opportunities for students to examine authentic written materials, it is also necessary to classify, just as in the case of authentic listening materials, written materials based on their initial objectives:

-Expository: The reader's main objective is to extract explained information as in the case of textbook writing, how-to articles, recipes, news stories (not including opinion or editorial pieces) and business, technical, or scientific writing.

-Descriptive: The reader's objective is to get specific details described about a character, event, or place as in poems, journals, diaries, nature writing and descriptive passages in fiction.

-Persuasive: The reader's objective is to be persuaded when reading biased arguments and opinions as in opinion and editorial newspaper pieces, advertisements, reviews (of books, music, movie, restaurants, etc.), letter of recommendation, letter of complaint and cover letters.

\footnotetext{
14 Jeremy Harmer, The Practice ..., 271.

${ }^{15}$ Paul Davies, Success in English Teaching (New York: Oxford University Press, 2000), 75.

${ }^{16}$ Rod Ellis, Understanding Second..., 129.

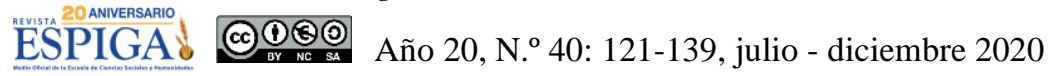


-Narrative: The reader's objective is to know about events, a person's life, a story or event. In narrative texts, the reader may find characters, dialogues, a logical sequence of events, actions, conflicts and solutions. Some examples of narrative texts are novels, short stories, novellas, poetry, autobiographies or biographies, anecdotes, and oral histories ${ }^{17}$.

After defining the reading objective of an authentic written material, EFL teachers have to examine the complexity or level of difficulty of the written text. To do this, Harmer explains that some researchers look at word and sentence length assuming that texts with long sentences and words will be more difficult to comprehend than a shorter one. Nevertheless, the author clarifies that others consider that «the critical issue is quite simply the number of unfamiliar words which a text contains. If readers do not know half the words in a text, they will have great difficulty in understanding the text as a whole ${ }^{18}$ ». Based on his review, students should have the skills to recognize naturally a great quantity of vocabulary, and longer chunks of sentences and phrases to improve their comprehension level. To do this, Davis suggests that the reader should go through a series of preparation stages such as coming up with previous ideas about the topic and evaluating his/her knowledge of the language and of the text. According to Beaugrande, Dressler, Carrell and Eisterhold, a reader's knowledge about the topic and language is called «schematic knowledge» which has great importance because if the learner is unaware of or has an erroneous idea about the topic in the message, wrong interpretations could be made and the comprehension process would fail. Moreover, Yule and Brown infer that successful comprehension is directly related to a reasonable interpretation of what the text is trying to communicate.

In an EFL classroom, the teacher should spend more time on teaching readers to comprehend authentic written materials, than testing reading comprehension. Nunan states that «monitoring comprehension is essential to successful reading» ${ }^{19}$. As part of the teaching methodology to ensure students' comprehensibility, the teacher should constantly verify that students' predictions are accurate and in cases when meaning is not correct, the teacher should invite students to make their adjustments and use further strategies to make progress.

The document «Transforming the English Classroom through Action-Oriented Teaching and Learning ${ }^{20}$ from MEP provides specific guidelines for the pedagogic mediation. Teachers should:

1. Present and explain learning objectives and expected outcomes of the task and assure that learners understand task instructions.

2. Ensure learners know how to use strategies through teacher scaffolding and modeling, peer collaboration and individual practice.

\footnotetext{
${ }^{17}$ Syed Hunbbel Meer, Four Different Types of Writing Styles: Expository, Descriptive, Persuasive, and Narrative (2016), accessed on March 20 ${ }^{\text {th }}, 2020$, https://owlcation.com/humanities/Four-Types-of-Writing

${ }^{18}$ Jeremy Harmer, The Practice..., 272.

${ }^{19}$ David Nunan, Practical English Language Teaching (New York: McGraw Hill, 2003), 75.

${ }^{20}$ Ministry of Public Education (MEP), Transforming the ..., 23-24. 


\section{What Can Authentic Materials Offer to Language Learning?}

The discourse identified in real communication contexts contrasts with the planned and properly structured language used in materials designed with educational purposes. Brown claims that there is a need for including authentic materials and contexts in the classroom so that EFL learners can start their linguistic preparation to face real life situations. He states that «authentic language and real-world tasks enable students to see the relevance of classroom activity to their long-term communicative goals $»^{21}$. More specifically, authentic materials bring the possibility of exploring colloquial language typical of real life speech, and other features such as:

-variations in speed of delivery, often fast, -natural intonation, -the natural features of connected speech, -variety of accents, -any grammatical structures natural to the topic, -incomplete utterances, -restructuring in longer, more complex sentences, -having speakers interrupt or speak at the same time, -having speakers use ellipsis (i.e. miss out parts of sentences), and -background noise. ${ }^{22}$

EFL learners also find the examination of authentic materials interesting and motivating since this training allows them to improve their comprehension skill and feel more confident when exposed to language typically found in mass media such as in television programs, the Internet and radio. In regards to the emotional effect of using authentic materials in the classroom, Gower, Phillips \& Walters ${ }^{23}$ provide the following reasons:

-For most students authentic materials, because they are 'real', are intrinsically more interesting and motivating and they give students confidence when they understand them.

-They provide examples of language as it is really used. By being exposed to authentic materials students have the opportunity to acquire or 'pick up' language.

-The real cultural content of many authentic materials encourages involvement and comparisons (especially in a multicultural group).

-Authentic materials lend themselves to authentic tasks: for example, getting information students may really need if they are planning a trip; listening to songs for pleasure; reading the menu of a restaurant they are going to eat in; etc.

-The use of authentic materials can be effectively linked with ways of helping students be more independent learners: making predictions and guesses, using reference books (grammar and vocabulary books, dictionaries).

When EFL teachers only use didactic materials in the classroom, learners experience a sense of «confidence» and create a wrong comprehensive reality. Learners get the

${ }^{21}$ Douglas Brown, Principles of Language Learning and Teaching (United States: Pearson, 2007), 258.

${ }^{22}$ Tricia Hedge, Teaching and..., 238.

${ }^{23}$ Roger Gower and Steve Walters, Teaching Practice..., 83. 
idea that when they are finished with their linguistic preparation, they are fully equipped with the necessary tools to face real life communication. Unfortunately, in many cases, when EFL learners are not exposed to materials that reflect an authentic use of the language, these learners tend to feel quite uncertain and frustrated when feeling they lack the skills to successfully communicate in the target language. For this reason, it is advisable to incorporate both types of materials, pedagogical and authentic, at different stages, so that learners are able not only to use English in academic contexts, but also out of the confines of the classroom. According to MEP, «It is very clear the teacher's profile in regards to learning to be and live in community when it states the how the teacher needs to be in the implementation of the new syllabus: Teacher supports critical and creative thinking processes beyond the class ${ }^{24}$.

In the same survey conducted to 35 EFL teachers from a variety of Costa Rican educational backgrounds, when they were asked to mention the advantages they identify when using authentic materials in the classroom, they wrote the following ${ }^{25}$ :

Table 3 Advantages identify using authentic materials

\begin{tabular}{|l|l|}
\hline Opinion 1 & $\begin{array}{l}\text { They give SS the opportunity to see what happens in real life. As } \\
\text { teachers we try to articulate and speak slowly so they can } \\
\text { understand what we are talking; however, «real people» do not } \\
\text { always take into account, and speak at a different pace (rhythm, } \\
\text { intonation, speed, etc.). }\end{array}$ \\
\hline Opinion 2 & $\begin{array}{l}\text { They are more attractive, interesting materials based on students' } \\
\text { needs and lifestyle. }\end{array}$ \\
\hline Opinion 3 & They enhance the opportunity to relate with real situations. \\
\hline Opinion 4 & $\begin{array}{l}\text { Those are materials that expose students to native speakers' accent } \\
\text { and show a real purpose of the use of the language. }\end{array}$ \\
\hline Opinion 5 & It helps students to get knowledge about real life situations. \\
\hline Opinion 6 & They provide real English in real life and updated situations. \\
\hline Opinion 7 & Students learn and have fun. \\
\hline Opinion 8 & Students learn to use the language in an specific scenario. \\
\hline Opinion 9 & The students feel identified with the activity. \\
\hline Opinion 10 & They are contextualized, updated and inclusive. \\
\hline
\end{tabular}

Source: Taken from survey, July 2019.

Based on the answers of the interviewed teachers, it is undeniably that they acknowledge the benefits of using authentic materials in the EFL classroom. They conclude and agree that language skills and subskills are greatly enhanced when incorporating them in their planning. Students foster their learning by using materials they usually encounter in their real contexts. Besides, the interviewed teachers appreciate the fact that these materials are highly motivating because they can relate

${ }^{24}$ Ministry of Public Education (MEP), Transforming the ..., 22.

${ }^{25}$ Margoth Arley and Tobias Brizuela, Survey July 2019. 
to students' real lives. On the other hand, since these materials display linguistic features that native speakers use, they equip students for dealing with situations where meaningful language needs to be used. In this sense, students can associate previous knowledge obtained from former classes with their current or future linguistic needs to be part of real life communication. In regards to the latter advantage, Master Josué Marín, Pedagogical English Advisor from MEP, Zona de los Santos, contributed to the topic by saying that «listening, speaking, reading, writing, grammar and vocabulary are usually boosted when using authentic materials ${ }^{26}$.

\section{The Role of Learning Strategies When Working with Authentic Materials}

To maximize students' confidence when examining authentic materials, EFL teachers need to provide guidance on the application of receptive strategies that can be used in a variety of activities. Nunan defines strategies «as conscious actions that learners take to achieve desired goals or objectives ${ }^{27}$. Strategies are understood as a creative sequence of actions that learners actively use in order to attain a specific language goal. As learners continue learning and practicing how to use specific strategies, the strategies move from conscious to unconscious. In other words, strategies can become automatic and the learners are capable of applying these strategies at different levels with different materials.

EFL students are required to monitor their level of comprehension when working on activities or exercises defined by the teacher. Even in elementary levels, EFL teachers can help students work on receptive strategies by inviting students to think about the way they are processing information, also known as metacognition. Nunan defines this concept as thinking about thinking. In other words, in the classroom, the teacher provides opportunities for students to select strategies that are useful to acquire knowledge. Nunan claims that «readers must monitor their comprehension processes and be able to discuss with the teacher and/or fellow readers what strategies they use to comprehend $»^{28}$. Depending on the results, students feel encouraged to keep using metacognitive strategies that help them process information even in future exercises or activities. Hence, it is essential to motivate students to apply a variety of learning strategies, considering that students learn in different ways and the teacher has to ensure that all learning skills are taken into consideration.

While examining an authentic material in class, there are diverse processes related to comprehension that the learner may study. According to Hedge, Peterson (as cited in Wilcox), and Brown, the first analysis process is «bottom-up», which uses knowledge related to the language to understand the new information provided in the written or aural text. During this process, the learner segments the information in terms of structures, sounds, and discourse types.

\footnotetext{
${ }^{26}$ Josué Marín (asesor pedagógico, Ministry of Public Education), individual survey, August 2019.

${ }^{27}$ David, Nunan, Practical English ..., 77.

${ }^{28}$ Ibíd., 75.

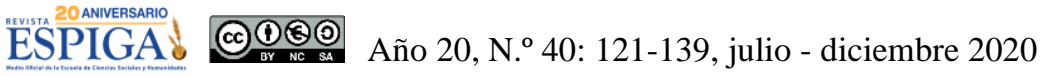


The second process to analyze the material is «top-down». As opposed to the first process, in this case, the learner adds information to the text from previous acquired knowledge. According to Hedge, this process is especially relevant because it is the one that provides the learner with the necessary context to understand the new information. Hedge says the learner «infers meaning from contextual clues and from making links between the spoken message and various types of prior knowledge which listeners hold inside their heads $»^{29}$.

More specifically, when the EFL teacher wants to incorporate aural authentic materials, students are given the possibility of listening to how native English speakers talk. To develop the skills to build up comprehensible knowledge, teachers should suggest which strategies are more useful depending on the listening objective. Holden, Brown and Hedge explain that since learners lack knowledge on vocabulary, contexts, varieties in accents, main ideas, and other aspects identified in authentic listening materials, EFL teachers can invite students to use the following bottom-up strategies:

- Activating existing information regarding words that the student thinks s/he will listen to in the text,

- Evaluating essential vocabulary with the help of the teacher,

- Changing words to improve comprehension,

- Using and contextualizing the new language,

- Personalizing the new vocabulary,

- Grouping and classifying grammatical structures,

- Self-monitoring to clarify their knowledge, asking questions or using the dictionary,

- Using grammatical structures as a guide to identify new vocabulary,

- Paying attention to the emphasis given to some sentences,

- Focusing on intonation patterns,

- Monitoring their production by reading out loud at the same time the speaker is speaking, and

- Collecting new vocabulary lists.

In addition to these strategies, Brown mentions that there are other effective topdown strategies that can be used in the classroom with the purpose of solving the lack of information about the topic, for example:

- Predicting the purpose of the speaker by the context of the spoken discourse,

- Associating the new information with already existing cognitive structures (activating related information),

- Identifying information presented by the teachers related to the meaning of the audio text,

- Expressing their emotions regarding the topic given in the audio material.

${ }^{29}$ Tricia Hedge, Teaching and..., 232.

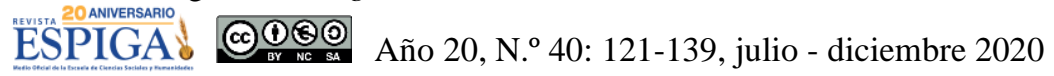


Likewise, Ur and Holden have contributed in the search for effective bottom- up and top-down strategies to face other problems, particularly gaps in the main ideas of the message and details of the audio material. These strategies include:

Table 4 Bottom- up and top-down strategies

\begin{tabular}{|l|l|}
\hline Bottom-up strategies & $\begin{array}{l}\text {-activating previously acquired knowledge to use } \\
\text { visual keys or hints that come from the environment, } \\
\text {-organizing text keys, and } \\
\text {-grouping lists of words by categories. }\end{array}$ \\
\hline Top-down strategies & $\begin{array}{l}\text {-using imagination to guess what will happen next, } \\
\text {-personalizing a situation with an already lived } \\
\text { experience, } \\
\text {-using imagination to guess the speakers' relationships } \\
\text { and where they are from, among other aspects, } \\
\text {-planning hearing goals, } \\
\text {-clarifying knowledge by asking questions, } \\
\text {-evaluating information according to relevance, taking } \\
\text { notes regarding what is known and has been heard, } \\
\text {-confirming predictions by evaluating himself/herself, } \\
\text {-paraphrasing to confirm his/her knowledge, and } \\
\text {-confirming what was understood by reading a text } \\
\text { related to the topic. }\end{array}$ \\
\hline
\end{tabular}

On the other hand, EFL teachers also need to guide students at applying a variety of strategies to obtain reading objectives. Nunan explains that «teaching them how to do this should be a prime consideration in the reading classroom ${ }^{30} \gg$. Students should have the possibility of not only becoming familiar with the types of reading strategies, but also knowing how to use them and integrate them in various reading situations.

As it was previously mentioned, students need to be invited to think about the way they process information by practicing metacognition. Some examples of strategies that students can practice applying when working with written materials are:

- Planning: previewing main ideas, making plans to accomplish a task, paying attention to key information, seeking out and arranging for conditions to promote successful learning.

- Monitoring: self-checking one comprehension.

- Evaluating: developing the ability to determine how well one has accomplished the task.

${ }^{30}$ David Nunan, Practical English..., 76. 
- Summarizing: saying or writing the main idea.

- Induction: figuring out the rules from samples of language.

- Imagery: being able to visualize a picture and use it to learn new information.

- Auditory representation: mentally replaying a word, phrase, or piece of information.

- Making inferences: using information in the text to guess the meaning.

- Using resources: developing the ability to use reference materials.

- Grouping: classifying words, terminology, quantities or concepts.

- Note-taking: writing down key words and concepts in verbal, graphic, or numerical form.

- Elaboration of prior knowledge: relating new to known information and making personal associations.

Sarig provides other strategies that learners can apply when examining authentic written materials which are classified into four types of moves:

- Technical-aid moves generally useful for decoding at a local level: skimming, scanning, skipping, writing key elements in the text, marking parts of text for different purposes, summarizing paragraphs in the margin, and using glossary.

- Clarification and simplification moves showing reader's intention to clarify and/or simplify text utterances: substitutions, paraphrases, circumlocutions, and synonyms.

- Coherence-detecting moves demonstrating the reader's intention to produce coherence from the text: effective use of content and formal schemata to predict forthcoming text; identification of people in the text and their views or actions; cumulative decoding of text meaning; relying on summaries given in the text; and identification of text focus.

- Monitoring moves displaying active monitoring of text processing, whether metacognitively conscious or not: conscious change of planning and carrying out the tasks; deserting a hopeless utterance (e.g., «I don't understand that, so I'll read on»); flexibility of reading rate; correction of mistakes; and ongoing self-evaluation. ${ }^{31}$

When students have the possibility of applying these strategies in several activities or exercises when examining authentic materials, they acquire the skills for successfully approaching authenticity in the classroom. Students feel more capable of processing information coming from authentic materials; hence, they gain more confidence to be part of real life conversations in the target language and leave their comfort zone exploring more challenging materials. As Ellis explains language acquisition is the result of the collaborative efforts of the learner and the teacher since both are involved in a dynamic interplay, establishing a meaningful learning environment where language communication becomes fluent and natural.

31 Abdo Mohammed Al-Mekhlafi, EFL Learners Metacognitive Awareness of Reading Strategies. International Journal of Instruction (2017), 297-308, accessed on February, $11^{\text {th }}, 2020$, from https://doi.org/10.12973/iji.2018.11220a

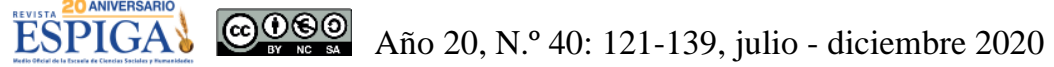


It is evident that incorporating all these strategies either bottom-up or top-down in the classroom becomes very challenging for teachers, mainly when having some particular conditions that tend to diminish the teaching learning process. However, the teacher might use one strategy per week and complement it with the use of authentic materials with the purpose of equipping the students for the real world. Undoubtedly, all efforts should take into consideration the actual conditions and might need some adaptations for the sake of the students' progress.

\section{Adapting Authentic Materials to Linguistic Levels}

When EFL teachers are planning to incorporate authentic materials in their class, they need to keep in mind that the language used in these materials is not modified in any sense since they are not intended for learners, but for English native speakers. Language is not adapted to specific levels and they respond to specific language communication needs and not to learners' linguistic goals. For this reason, in order to avoid confusion and demotivation, EFL teachers should make adaptations in these materials, always ensuring that the material keeps its essential and natural presentation. Depending on the learners' level, the EFL teacher needs to make slight or meaningful changes to the language use. Moreover, the teacher can show learners how authentic materials are used in real life situations and motivate them to keep examining them outside the classroom.

Based on the latest teaching approaches, the main communication goal is not only to enhance the application of the receptive skills, but also the productive skills. This is important to clarify so that especially low level learners don't feel demotivated or frightened to examine them. Learners need to keep in mind that context is the key to meaning and they can remove difficult words or unknown vocabulary to build up comprehension. Besides, the teacher can provide a vocabulary glossary and invite students to participate in pre, while or post written or aural exercises to ensure meaningful learning. During the planning stage, Pinner advises EFL teachers to ask themselves the following questions when selecting an authentic material ${ }^{32}$ :

- Do I (the teacher) find this content stimulating?

- Will my learners find this interesting?

- Is it suitable for my learners? (difficulty, age)

- How does it fit in with the other work we are doing in class?

- Will this be useful to them? (assessment, future goals)

After critically answering these questions, the EFL teacher needs to make the necessary adaptations in authentic materials depending on the learners' levels. Shepherd classifies the use of authentic materials based on learners' level, considering what they are capable of doing with the language:

${ }^{32}$ Richard Pinner, Using and Adapting Authentic Materials to Help Motivate Students (n.d), accessed on March, 20 ${ }^{\text {th }}$, 2020, from: http://uniliterate.com/2015/08/adaptingauthentic-materials-motivate-students/\#.XQPTEtJKjcs, 3 .

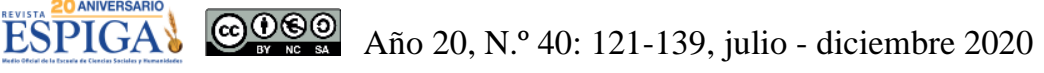


At lower levels: Learners can examine simple and short authentic materials such as leaflets, timetables, menus, short headline type reports, audio and video advertising, or short news broadcasts. The task should be simple and relatively undemanding, and it is important to pre-teach key vocabulary so as to prevent panic.

At more intermediate levels: Learners can analyze longer articles, four or five-minute TV or radio news reports, a higher quantity of shorter items, or even whole TV programmes, if your copyright agreements allow it. Again pre-teaching is important, although your students should be able to deal with unknown vocabulary to some extent.

At higher levels: learners should have some tactics for dealing with new vocabulary without panicking, but it is still useful to have a few quick definitions to hand for some of the trickier stuff. ${ }^{33}$

\section{Practical Implications of Using Authentic Materials}

One of the most rewarding parts when including authentic materials in the lessons deals with the practical implications for the students in the classroom. Throughout the whole article those implications have been clearly mentioned; however, it would be very useful to point them out again.

These implications can relate to different aspects of the learning process; for example, some convey to the emotional effect, some others focus on cultural immersion while others help students prepare for real life contexts.

In regards to the emotional effect, EFL learners find the examination of authentic materials interesting and motivating since this training allows them to improve their comprehension skill and feel more confident when exposed to language typically found in mass media such as in television programs, the Internet and radio.

When considering cultural immersion, authentic materials in the class help students boost and maximize their language acquisition process. They feel encouraged to keep using metacognitive strategies that equip them to process information even in future exercises or activities.

Finally, students feel more capable of processing information coming from authentic materials; hence, they gain more confidence to be part of real life conversations in the target language and leave their comfort zone exploring more challenging materials at the same time and providing them with opportunities to extract information meaningfully and get prepared to face real life communication.

\section{Final Observations}

The teaching learning process is a complex one that considers many aspects in order to equip students to become effective communicators in the target language. One of these aspects is the one related to didactic materials. An effective teacher will carefully pay attention to the selection of different materials he/she can take advantage of with the sole intention of maximizing the assimilation of the contents being mediated in the EFL classroom.

33 Sam Shepherd, Using Authentic Materials. (n.d), accessed on April 14 ${ }^{\text {th }}$, 2020, from https://www.teachingenglish.org.uk/article/using-authentic-materials

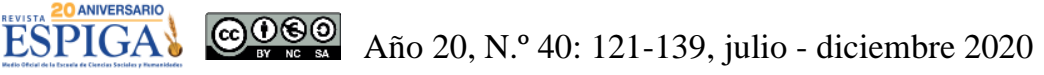


As explained in this article, authentic materials become a great source of input, vocabulary, idiomatic expressions and grammar structures that native speakers use in their everyday contexts and can perfectly be taken into consideration when organizing and planning the contents to teach. Although it is clear that these authentic materials were not intended for pedagogical purposes, teachers in all contexts and levels can consider all these linguistic features within their lesson plans to prepare students to face the real world and give them tools to enhance their language learning process.

Contrary to traditional practices in which the textbook was thought as the most effective resource to guide students' learning process and because of the current linguistic demands of this globalized world, English teachers have been making necessary adaptations to their teaching practices and have been introducing resources that can reveal a more genuine use of the target language. In this context, to ensure the correct application of authentic materials, teachers have to comprehend that there are various aspects to keep in mind when planning their lessons. As it was previously explained in various sections in this article, some of these considerations are regarding their main characteristics, their listening and reading goals, their impact in different students' levels, their advantages, the learning strategies and activities that can be applied to examine their language use, among others.

\section{Formato de citación según APA}

Arley-Fonseca, M. y Brizuela-Gutiérrez, T. (2020). Enhancing the Language Learning Process of Students in the Costa Rican Educational System by Considering the Use of Authentic Materials in the EFL Classroom. Revista Espiga, 20 (40), páginas 121-139

\section{Formato de citación según Chicago-Deusto}

Arley-Fonseca, Margoth y Tobías Brizuela-Gutiérrez. «Enhancing the Language Learning Process of Students in the Costa Rican Educational System by Considering the Use of Authentic Materials in the EFL Classroom». Revista Espiga 20, n. ${ }^{\circ} 40$ (julio-diciembre, 2020): páginas 121-139

\section{Works cited}

Al-Mekhlafi, A. EFL Learners Metacognitive Awareness of Reading Strategies. International Journal of Instruction. 2017, 11(2). Retrieved from https://doi.org/10.12973/iji.2018.11220a

Brown, D. Teaching by principles. New York: Addison Wesley Longman, 2001.

Brown, D. Principles of Language Learning and Teaching. United States: Pearson, 2007. 
Brown, G., Yule. «Dimensions of difficulty in listening comprehension». In Mendelsohn, D., Rubin, J. (Ed.). A Guide for the Teaching of Second Language Listening. San Diego, California: Dominie Press, 1995.

Davies, P. Success in English Teaching. New York: Oxford University Press, 2000.

Rod Ellis. Understanding Second Language Acquisition. New York: Oxford University Press, 1999.

Gower, R., Phillips, D. \& Walters, S. Teaching Practice: A handbook for teachers in training. Thailand: Macmillan, 1995.

Harmer, J. The Practice of English Language Teaching. England: Pearson, 2008.

Hedge, T. Teaching and learning in the language classroom. New York: Oxford University Press, 2000.

Holden, B. «Listen and learn». English Teaching Professional. London: Helen Gomm, 2002.

Hunbbel, S. Four Different Types of Writing Styles: Expository, Descriptive, Persuasive, and Narrative. 2016. Retrieved from https://owlcation.com/humanities/Four-Types-of-Writing

MEP. Transforming the English Classroom through Action-Oriented Teaching and Learning. San José, Costa Rica, 2016.

Nunan, D. Practical English Language Teaching. New York: McGraw Hill, 2003.

Pinner, R. (n.d). Using and Adapting Authentic Materials to Help Motivate Students. Retrieved from: http://uniliterate.com/2015/08/adapting-authenticmaterials-motivate-students/\#.XQPTEtJKjcs

Richards, J. \& Renandya, W. Methodology in Language Teaching. Cambridge University Press, 2002

Shepherd, S. (n.d). Using Authentic Materials. Retrieved from https://www.teachingenglish.org.uk/article/using-authentic-materials

Ur, P. A course in language teaching. New York: Cambridge University Press, 2003.

Wilcox, P. «Skills and strategies for proficiency listening». En M.Celce-Murcia (Ed.), Teaching English as a Second or Foreign Language. Boston: Heinle and Henle Publishers, 2001. 